\title{
Potential of Leucas zeylanica extract to eliminate E. coli and S. aureus in Corbicula fluminea ("Etak") tissue
}

\author{
Faizuan Abdullah ${ }^{a},{ }^{*}$, Siti Nor Aini Md. Nasir ${ }^{b}$, Dee Koh Han ${ }^{b}$, Suganthi Appalasamy ${ }^{b}$, Maryana \\ Mohamad Nor ${ }^{c}$, Aweng Eh Rak b, *
}

a Department of Chemistry, Faculty of Science, Universiti Teknologi Malaysia, 81310 UTM Johor Bahru, Johor, Malaysia

${ }^{b}$ Department of Natural Resources and Sustainability, Faculty of Earth Science, Universiti Malaysia Kelantan, 17600, Jeli, Kelantan, Malaysia

c Faculty of Agro Based Industry, Universiti Malaysia Kelantan, 17600, Jeli, Kelantan, Malaysia

* Corresponding author: faizuan@utm.my, aweng@umk.edu.my

\section{Article history}

Received 2 August 2018

Revised 10 September 2018

Accepted 26 February 2019

Published Online 25 August 2019

Graphical abstract

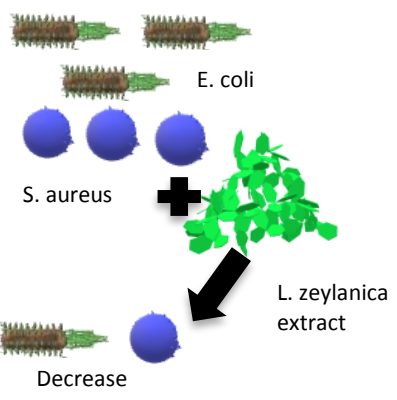

\begin{abstract}
"Etak" or Corbicula fluminea, is a freshwater mollusc species regularly consumed as a popular snack among the Kelantanese in Malaysia. The "etak" is usually heated with traditional smoking process which is considered as half cooked and the smoked $C$. fluminea is commonly known as "etak salai". This study focuses on the potential of Leucas zeylanica leaves extract to eliminate the bacteria content in "etak salai". Extraction of bacterial genomic DNA was performed and confirmed the existence of Escherichia coli (E. coli) and Staphylococcus aureus (S. aureus) in "etak salai". Antibacterial properties of $L$. zeylanica leaves extract was identified using disc diffusion assay and the result obtained exhibit that $70 \mu \mathrm{g} / \mu \mathrm{L}$ of $L$. zeylanica extract was the optimum concentration to give the effect of $11 \mathrm{~mm}$ inhibition zone for $E$. coli and $15 \mathrm{~mm}$ inhibition zone for $S$. aureus. This finding proof that $L$. zeylanica leaves could be the ingredients in the paste for "etak salai" preparation.
\end{abstract}

Keywords: Corbicula fluminea, etak, Leucas zeylanica, antibacterial, E. coli, S. aureus

\section{INTRODUCTION}

Traditionally, the smoking process of $C$. fluminea involves three steps of preparations. The first step is cleaning process to remove all the mud covered on the "etak" shells. The second step is mixing process, where the blended spices and salt is prepared as a paste to mix with the "etak" for the flavor. While, the third step is the smoking process of the $C$. fluminea on the special bench structure with the slow burning woods underneath as a smoke source. The temperature of the "etak salai" during the smoking process was measured below $55^{\circ} \mathrm{C}$ and normally smoked for maximum time of 45 minutes and must ensure the "etak salai" shells are not open when cooked [1]. The previous study identified that the minimum temperature for bacteria killing in food especially mollusk is $70{ }^{\circ} \mathrm{C}$, and must cooked until the shells open for clams and mussel, Thus, the smoking process for "etak salai" at temperature below $60{ }^{\circ} \mathrm{C}$ is not suitable as it could be harmful to the consumer if the bacteria is not completely killed [2]. Fig. 1 displays the preparation steps for "etak salai".

An antibacterial spices or herbs was included in the "etak salai" marinating ingredients in order to eliminate the potent bacteria species that could contaminate. L. zeylanica or known as "Ketumbit" by the local are abundantly distributed in the bushes of Malaysia especially Kelantan. From the previous findings, several benefits of $L$. zeylanica such as anti-inflammatory, analgesic, anti-diarrheal, antimicrobial, antioxidant, and insecticidal activities have been reported [3] [4]. The microbs such as $E$. coli and coliforms growth were inhibit when exposed to leaves extract of L. zeylanica. [5]

This weed species normally grows at sandy soils area especially near to the seashore with maximum height of $30 \mathrm{~cm}$. It is also well known as Ceylon slitwort and normally used at India, as a spices to provide a bitter flavor. It is also applied as a cure for insects and poisonous bite, jaundice, healing wounds and as well as for stomach ache relief especially due to roundworms for children. The plant morphology consists of its leaves, flowers, fruits, stems and roots as explained in Fig. 2. [6].

Therefore, the aim of the study was to evaluate the potential of methanolic extract of leaves of $L$. zeylanica for its antimicrobial activity against $E$. coli and $S$. aureus. Thus, it could be consider as one of the ingredients for the "etak salai" paste to avoid gastrointestinal infection among the consumers.

\section{EXPERIMENTAL}

\section{Sampling and sample preparations}

Extraction of DNA from fresh and smoked $C$. fluminea was done following the method used from the previous study to determined the microbial DNA from environmental samples [7]. A total of 100-150 pieces of fresh and smoked $C$. fluminea samples were collected from Kampung Kasar, Pasir Mas from August to December 2017. The samples was then well mixed and cone and quarter method was performed to select only 5 pieces of the fresh and smoked $C$. fluminea for further analysis. The samples together with DNA markers, were electrophoresed on $1 \%$ agarose gel containing ethidium bromide $(5 \mu \mathrm{g} / \mu \mathrm{L})$, submerged in tris-borate EDTA (EDTA-TBE) buffer. The gels for electrophoresis used in this study were prepared by boiling $1 \%$ agarose powder in EDTA -TBE buffer solution, together with $2 \mu \mathrm{L}$ of ethidium bromide, and poured into a mould after being cooled to $50^{\circ} \mathrm{C}$. 


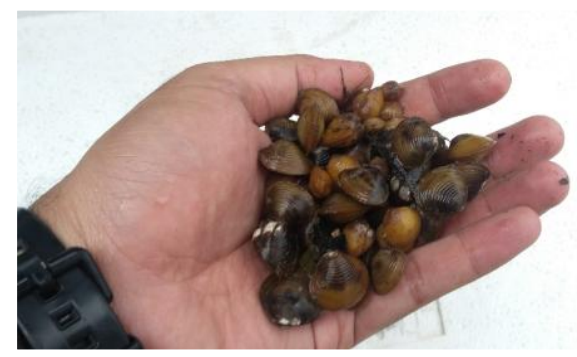

(a)

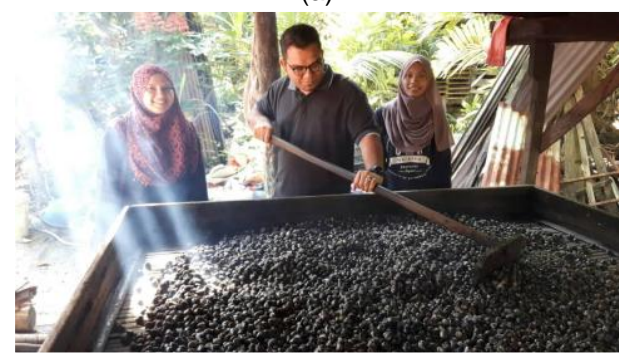

(b)

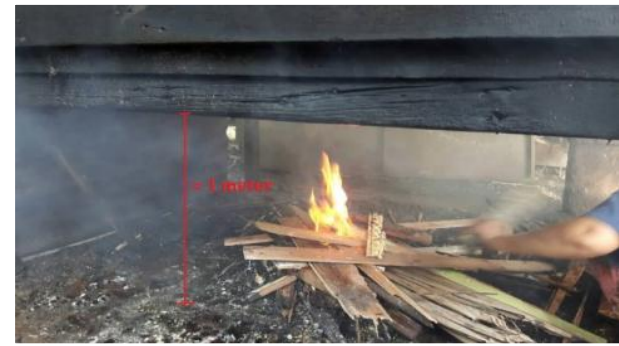

(c)

Fig. 1. (a): Yellowish etak from Kelantan's river, (b): the smoking process on the smoking bench for at Kg. Kasar, Pasir Mas, Kelantan, (c): the height of etak smoking bench from the ground.

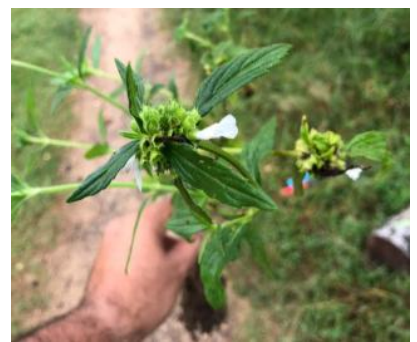

(a)

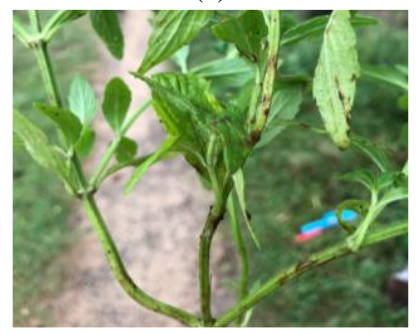

(b)

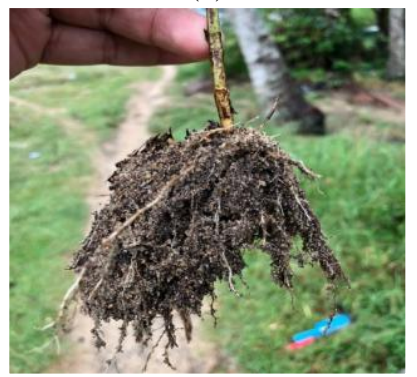

(c)

Fig. 2 L. zeylanica (ketumbit), (a): leaves, flowers and fruits, (b): aerial part, (c): roots.
While the agarose are cooling, the solution was then poured into the gel. Before starting electrophoresis using an electrophoresis machine, the gel was submerged in a TBE buffer containing ethidium bromide at $5 \mu \mathrm{L} / \mathrm{mL}$ concentration. Using a $10 \mu \mathrm{L}$ micro pipette, the samples which had already been mixed with a loading dye were loaded into wells of the prepared gel. From that point onward, the top of the gel tank was shut and the electrical lead was connected in light of the fact that the DNA will move toward the positive anode. Electrophoresis was run at $115 \mathrm{~V}$ for $90 \mathrm{~min}$. The gel was removed and placed directly on a UV transilluminator. Subsequently, the band energy of the samples were visualized and captured using a UV transilluminator.

The healthy mature plants of L. zeylanica were collected from Pulau Gajah, Pengkalan Chepa Kelantan (6 09'40.9'N). Identification of the plant was authenticated at herbarium of UKM with voucher number of UKMB40376. The plants leaves were cut, wash with distilled water and dried in oven $37^{\circ} \mathrm{C}$ for 3-4 days until fully dried. The leaves were ground to a fine texture or become powder form using a grinder and stored at $4^{\circ} \mathrm{C}$. After that, $50 \mathrm{~g}$ of shade-dried pulverized plant leaves were subjected to extraction in a Soxhelet apparatus using methanol (Merck, 70\%). The extract obtained was filtered using membrane filter paper. The filtrate was concentrated under vacuum in a rotary evaporator $\left(80^{\circ} \mathrm{C}, 110 \mathrm{RPM}\right)$ and stored at $4^{\circ} \mathrm{C}$ until further use [8].

\section{Antibacterial activity of $L$. zeylanica leaves extract}

The bacterial spp. used for the test were E. coli and S. aureus. All the stock cultures were obtained from Microbe Technology Laboratory, Universiti Malaysia Kelantan. Bacterial strains preserved in nutrient agar at $4^{\circ} \mathrm{C}$ were revived in nutrient broth (liquid medium) and incubated at $37 \pm 1{ }^{\circ} \mathrm{C}$ overnight. For testing of the anti-bacterial activity Nutrient Agar medium (NAM) was used. The medium was sterilized for $20 \mathrm{~min}$ at $121^{\circ} \mathrm{C}$ and the antimicrobial activity was examined by pouring about $15 \mathrm{ml}$ of the medium into $10 \mathrm{~cm}$ petri dishes under aseptic condition and left undisturbed for $2 \mathrm{hrs}$ to solidify the medium. Paper discs impregnated with different concentration of extraction are placed on the surface of the nutrient agar medium. The plates are incubated and the zones of inhibition around each dish are measured. The disc diffusion assay methods Gebreyohannes et al., 2013 with modifications, were used to determine bacterial growth inhibition by leaf extracts. Diluted E. coli and $S$. aureus bacterial culture $(10 \mu \mathrm{l})$ were spread over nutrient agar plates with a sterile glass L-rod. $20 \mu \mathrm{l}$ of the each extract were applied to each filter paper disc (Whatman No. 1, 6 $\mathrm{mm}$ diam.) and allowed to dry before being placed on the agar plate. Each extract was tested in triplicate ( 3 discs/plate) and the plates were inoculated at $37 \pm 1^{\circ} \mathrm{C}$ for $24 \mathrm{~h}$. After incubation, the diameter of the inhibition zones was measured with a calliper. Data from antibacterial activity were expressed as a mean $( \pm \mathrm{SD})$ followed by a pair wise comparison of means (Tukey) for each analysis. Comparative statistical analysis between means was calculated with the Minitab 17.0.

\section{RESULTS AND DISCUSSION}

Usually the A260/230 values for "pure" nucleic acid are higher than the ratio of A260/280 values. The range of expected values of A260/230 commonly is 2.0-2.2. If the ratio is appreciably lower than expected, it may indicate the presence of contaminants which absorb at $230 \mathrm{~nm}$. Table 1 below displays the results of fresh $C$. fluminea samples with the DNA concentration of $33.75 \mathrm{ng} / \mu \mathrm{L}$ while the $260 / 280$ was 1.53 and 260/230 was 1.69. Besides, the results also indicate that smoked $C$. fluminea samples with the DNA concentration is $80.59 \mathrm{ng} / \mu \mathrm{L}$ while the $260 / 280$ was 1.94 and $260 / 230$ was 1.87 . The ratio $260 / 230$ and 260/280 for fresh $C$. fluminea were below 1.8 and indicates the existence of contaminants, while it was oppositely for smoked etak $C$. fluminea. Moreover, the samples were further analysed and confirmed the presence of $E$. coli and $S$. aureus bacteria and it was much higher in the smoked $C$. fluminea or "etak salai".

The E. coli and $S$. aureus obtained from the smoked $C$. fluminea were then being cultured for further experiment of bacteria inhibition using the extract of $L$. zeylanica leaves extract. The antibacterial activities of the leaf extracts of $L$. zeylanica are summarised in Table 2. 
The data obtained shows the trend of influence of the methanolic leaves extract in different concentrations, against two tested bacterial strains. The highest antibacterial activities for the methanolic leaf extracts against $E$. coli and $S$. aureus was $70 \mu \mathrm{g} / \mu \mathrm{L}$, with zones of inhibition of $10.6 \mathrm{~mm}$ and $14.8 \mathrm{~mm}$ respectively. Generally, inhibition of bacteria increases with corresponding increase in the volume of plant extract as it contains more concentration of a particular or group of antibacterial compounds. However, for this study it showed that the increment of extraction dosage may cause some biological effects which may interfering the efficacy of the inhibition.

Table 1: The concentration and ratio of A260/280 and A260/230 for DNA extraction.

\begin{tabular}{ccccc}
\hline No & Samples & $\begin{array}{c}\text { DNA } \\
\text { Concentration } \\
(\mathbf{n g} / \mathbf{\mu L})\end{array}$ & A260/280 & A260/230 \\
\hline $\mathbf{1}$ & Fresh & 33.75 & 1.53 & 1.69 \\
$\mathbf{2}$ & Smoked & 80.59 & 1.94 & 1.87 \\
\hline
\end{tabular}

Table 2. Inhibition zone of $L$. zeylanica leaves extract (Disk diffusion assay method).

\begin{tabular}{lccc}
\hline \multirow{2}{*}{ Extract } & $\begin{array}{c}\text { Concentration } \\
(\boldsymbol{\mu g} / \boldsymbol{\mu L})\end{array}$ & E. coli & S. aureus \\
\cline { 3 - 4 } & 50 & $10.2 \pm 0.1$ & $14.0 \pm 0.1$ \\
& 60 & $10.5 \pm 0.9$ & $14.4 \pm 0.1$ \\
& 70 & $10.6 \pm 0.2$ & $14.8 \pm 0.1$ \\
& 80 & $10.0 \pm 1.1$ & $14.3 \pm 0.4$ \\
& 90 & $9.6 \pm 0.7$ & $13.6 \pm 0.3$ \\
& Antibiotic & 15.0 & 16.4 \\
& (gentamicin) & 27.0 & 34.2 \\
\hline Methanol & &
\end{tabular}

Both of the bacteria tested in this study are classified as gramnegative bacteria, and their resistance may be associated with the cell wall structure. Gram-negative bacteria have an effective permeability barrier, composed of outer membranes of lipopolysaccharides which can restrict penetration of plant extracts. It has been reported previously that Gram-negative bacteria are usually more resistant to plant-derived antimicrobials and do not even show an effect, compared to Grampositive bacteria [9]. Gram-positive bacteria have peptidoglycan layers such as mesh that are more easily obtained by gems by extract [10] Results revealed that the leaves extract from Leucas zeylanica showed prominent antibacterial. Furthermore, the active ingredients of parts of plant are better than extracts with methanol than chloroform [11].

In this study, the zone of inhibition produced by the commercial antibiotic, gentamicin was larger than those produced by all methanol extracts. It may be attributed to the fact that the plant extracts contained in the raw form contain a small bioactive concentration [12]. In classifying antimicrobial activity, it is generally expected that larger numbers will be active against Gram positive than negative Gram bacteria [13]. However, in this study, leaf extracts are effective against both Gram positive bacteria and Gram negative. Activity against both types of bacteria may indicate the presence of a broad spectrum of antibiotic compounds or only general metabolic toxins [12].

In previous studies, whole plant extracts of Leucas aspera were assessed for antimicrobial activity. It has been found that the reach of higher inhibition zones was observed for S. aureus, E. coli, and $P$. aeruginosa [14].

\section{CONCLUSION}

This work was devoted to access the capability of methanolic leaf extract of $L$. zeylanica to obtain the optimum concentration for the inhibition of E. coli and $S$. aureus. It was found that $70 \mu \mathrm{g} / \mu \mathrm{L}$ gave the best effect. This was the first report that $L$. zeylanica showed potential antibacterial activity against $E$. coli and $S$. aureus that contaminating the smoked $C$. fluminea. Thus, the $L$. zeylanica weed which is abundantly distributed in Malaysia could be considered as one of the ingredients for the preparations of "etak salai" to avoid gastrointestinal infection among the consumers. This finding could give an economic impact to the "etak salai" business in Kelantan.

\section{ACKNOWLEDGEMENT}

This work was financially supported by the Ministry of Education Malaysia under the Trans Diciplinary Research Grant (TRGS) at Universiti Malaysia Kelantan and Research University Grant (Q.J130000.2654.16J57) by Universiti Teknologi Malaysia.

\section{REFERENCES}

[1] Shamsul, Z. N. M., A. E. Rak, S. H. Samae, S. A. S. Omar, L. A. Afip, Preliminary assessment of Corbicula fluminea in Saiburi river, Southern Thailand. Borneo Journal of Resource Science and Technology, 2017. 7(2): 76-83.

[2] Kharel, K., V. K. Yemmireddy, C. J. Graham, W. Prinyawiwatkul, A. Adhikari, Hot water treatment as a kill-step to inactivate Escherichia coli O157:H7, Salmonella enterica, Listeria monocytogenes and Enterococcus faecium on in-shell pecans. LWT, 2018. 97: 555-560.

[3] Das, S. N., V. J. Patro, S. C. Dinda, A review: Ethnobotanical survey of genus Leucas. Pharmacognosy Reviews, 2012. 6(12): 100-106.

[4] Saritha, K., A. Rajesh, K. Manjulatha, O. H. Setty, S. Yenugu, Mechanism of antibacterial action of the alcoholic extracts of Hemidesmus indicus (L.) R. Br. ex Schult, Leucas aspera (Wild.), Plumbago zeylanica L., and Tridax procumbens (L.) R. Br. ex Schult. Frontiers in Microbiology, 2015. 6(577): 1-9.

[5] Zhang, X., M. Gui, C. Zhang, C. Chen , L. Yu, J. Liu, Leucasinoside: A new abietane diterpenoid glycoside from Leucas zeylanica. Records of Natural Products, 2016. 10(5): 645-648.

[6] Napagoda, M. T., B. M. A. S. Malkanthi, S. A. K. Abyawardana, M. M. Qader, L. Jayasinghe, Photoprotective potential in some medicinal plants used to treat skin diseases in Sri Lanka. BMC Complementary and Alternative Medicina, 2016. 16(1): 479.

[7] Tanase, A.-M., L. Mereuta, L. Chiciudean, R. Lonescu, L. Milea, C. P. Cornea, T. Vassu, I. Stoica, Comparison of total DNA extraction methods for microbial community form polluted soil. Agriculture and Agricultural Science Procedia, 2015. 6: p. 616-622.

[8] Babu, A., M. S. N. Mohamed, K. Jaikumar, D. Anand, P. Sarvanan, Invitro antifungal activity of leaf extracts of Leucas aspera and Leucas zeylanica. International Journal of Pharmaceutical Sciences and Research, 2016. 7(2): p. 752-756.

[9] Gebreyohannes, E. A., A. S. Bhagavathula, B. M. Gebresillassie, Y. G. Tefera, S. A. Belachew, D. A. Erku, Recreational use of phosphodiesterase 5 inhibitors and its associated factors among undergraduate male students in an Ethiopian University: A crosssectional study. Value in Health, 2016. 19(7): A394.

[10] Biswas, B., K. Rogers, F. McLaughin, D. Daniels, A. Yadav, Antimicrobial activities of leaf extracts of guava (Psidium guajava L.) on two gram-negative and gram-positive bacteria. International Journal of Microbiology, 2013. 2013: 1-7.

[11] Stefanello, M. É. A., A. C. Cervi, I. Y. Ito, M. J. Salvador, A. W. Jr, E. L. Simionatto, Chemical composition and antimicrobial activity of essential oils of Eugenia chlorophylla (Myrtaceae). Journal of Essential Oil Research, 2008. 20(1): 75-78.

[12] Singh, M. K., A. Pandey, H. Sawarkar, A. Gupta, B. Gidwani, H. Dhongade, D. K. Tripathi, Methanolic extract of Plumbago zeylanica - A remarkable antibacterial agent against many human and agricultural pathogens. Journal of Pharmacopuncture, 2017. 20(1): 18-22.

[13] Chew, A. L., J. J. A. Jessica, S. Sasidharan, Antioxidant and antibacterial activity of different parts of Leucas aspera. Asian Pacific Journal of Tropical Biomedicine, 2012. 2(3): 176-180.

[14] Malanovic, N., K. Lohner, Antimicrobial peptides targeting grampositive bacteria. Pharmaceuticals, 2016. 9(3): 59.

[15] Srinivasan, D., S. Nathan, T. Suresh, P. L. Perumalsamy, Antimicrobial activity of certain Indian medicinal plants used in folkloric medicine. Journal of Ethnopharmacology, 2001. 74(3): 217-20. 